\title{
DESIGN AND CONSTRUCTION OF MULTITIER SHORING TOWERS
}

\author{
K.M.Shawki*; M.A.Emam**; El-B. Osman ${ }^{\star * *}$ \\ "Associate prof., College of Eng. and Technology, AASTMT, \\ Alexandria, Egypt. \\ ** Professor, College of Eng. and Technology, AASTMT, Cairo, Egypt \\ ${ }^{* * *}$ M.Sc. College of Eng. and Technology, AASTMT, Alexandria, Egypt
}

(Received January 29, 2012 Accepted February 15, 2012)

\begin{abstract}
The construction of heavy and high concrete slabs is considered as a great problem in projects because they need very efficient formwork systems. The multi-tiers shoring towers (as vertical supporting members) appears as the common solution for this problem in addition to plywood sheathing, steel, wood,aluminum as joists, stringers as secondary and main beams. The multi-tiers shoring towers are made of painted steel, galvanized steel or aluminum, they are modular, can be used a large number of time, much faster to erect and have high loading capacity. According to increase in demand for this type, the reason to study them is extremely needed. This paper determines the minimum weight of slab formwork using this system. The genetic algorithm is used as an optimization technique. An example is provided to illustrate the design procedure. The design procedure is shown through a computer model called OSAF.
\end{abstract}

KEYWORDS: Formwork, optimization, multitier

\section{INTRODUCTION}

Formwork for heavy and high-clearance concrete construction is commonly based on multitier shoring towers, also termed load towers or support towers, which essentially are "frame based" systems, to distinguish from "tube and coupler" systems. Thus, shoring towers of various heights are an inseparable part of the construction scene in commercial, residential, industrial, public, and civil engineering projects all over. Demand for their use has grown even more since erection and dismantling convenience renders such towers also a likely shoring solution for low-clearance construction, where single props have traditionally been used. Furthermore, towers often serve as temporary supports in precast concrete construction, and even as access scaffolds. Figure (1) illustrates the centrality and versatility of shoring towers in their various capacities.

Today's well recognized books on formwork (Hurd M. K., 1995), (Peurifoy \& Oberlender, 1996), and (Hanna, 1999) pay only limited attention to shoring towers, usually within the general presentation of vertical shoring solutions, and expansive chapters in books, dealing exclusively with towers, are scarce (Bennett \& D'Alessio, 1996). Technical manufacturer catalogues traditionally provide useful information on specific products. Various economic aspects of formwork design and practice with shoring towers have been treated during recent years, with special focus on high multitier towers (Shapira, 1995), (Shapira \& Goldfinger, 2000), and (Shapira, Shahar, 
\& Raz, 2001), (Shapira, 2004). Those studies on high towers, were motivated mainly by the high cost of tower-based formwork relative to the overall construction cost of the supported concrete element, which is significantly higher than the common estimates of 40-60\%, that are in themselves quite high (Hanna, 1999).


Figure (1): Example tower configurations. (Shapira \& Raz, 2005)

Shoring towers are made up of hand carried elements and are assembled anew for each use; they may be regarded as conventional formwork. Their industrialized nature, however, is distinct: 1) they are modular; 2) they are made of steel or aluminum and can be reused a large number of times; 3 ) when erected to great heights (and often for lower heights as well) they are usually preassembled in short modules on the ground and then craned to their final location very much the same as any other industrialized forming systems; and 4) they often make up the vertical shoring of industrialized table forms. The important of shoring towers also stems from the fact of their impact on the cost of forming heavy and high-clearance situations is significant.

Based on a survey of currently available and commonly used tower models, the shoring towers had addressed with carrying capacities of $45-80 \mathrm{kN}$ per leg. Towers in this class, i.e., heavy duty towers, are those used extensively in building construction, and to some extent also in civil engineering projects (e.g., highway and bridge construction). The next class, of extra-heavy-duty towers, includes towers with carrying capacities of up to $200 \mathrm{kN}$ per leg, mostly used for heavy civil projects. One may justifiably argue that the $100-130 \mathrm{kN}$ per-leg range should belong in the heavyduty class. It should be borne in mind, though, that with the typical building construction loads on the one hand, and the size of the elements commonly used as stringers and joists [which limit tower spacing (Shapira \& Goldfinger, 2000) on the other hand, a $120 \mathrm{kN}$ per-leg tower is likely to be extremely underutilized in most cases of "regular" building construction. 


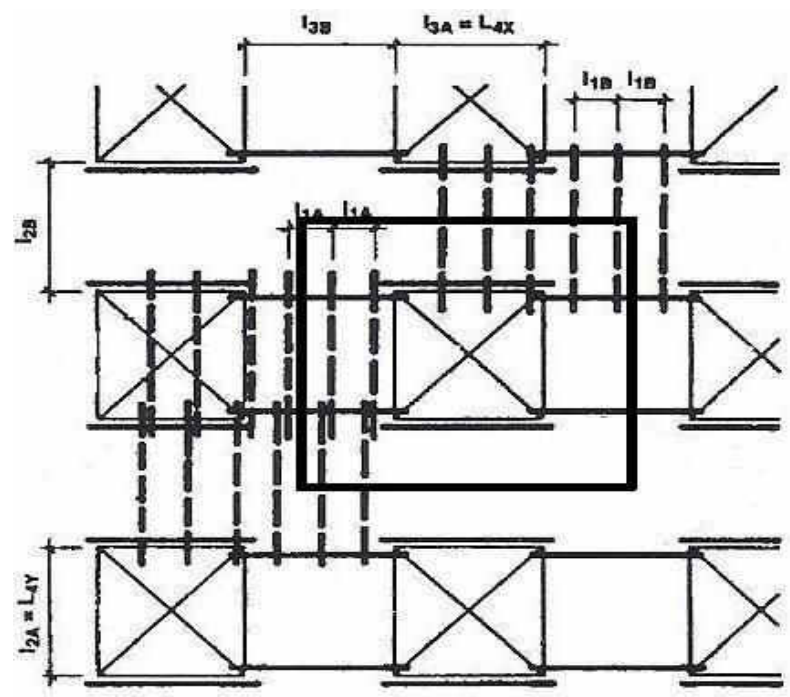

Figure (2): The area carried by one shoring tower.

A number of studies are conducted based on an approach called Rational Design, which is mean design based on a structured procedure that yields solutions that both meet the static requirements and are economical. These studies whether general [e.g., (Peurifoy R. L., 1976), and (Hurd, 1989)] or specific [e.g., (Ringwald, 1985)]. Typically addresses conventional formwork design with a rational approach for common concrete elements (e.g., regular-height slabs, beams, and walls). Several studies [e.g., (Christian, 1987), and (Tah \& Price, 1991)] have taken the issue even further and developed computerized solutions. However, one type of conventional formwork-although widely used-has received little attention with regard to rational design, this type is formwork for elevated (i.e., heavy and higher than normal) elements having steel or aluminum shoring towers as the form's main vertical support.

But all previous studies focused only on giving correct and organized approach and may some of them computerized they approaches and all these efforts was helpful and definite introduce methods help in reducing time and cost. This paper will go further to introduce a method not only structured or computerized but also with optimization in formwork weight based on genetic algorithms as an optimization tool to get the optimal solution with the minimum weight which is lead to reducing in time and cost. Although shoring towers are sometimes used for other purposes than concrete formwork such as temporary support scaffolds for precast concrete elements or as access scaffolds for workers, tools, and materials. The present paper treats shoring towers only as formwork.

Although the similarity between shoring towers in their overall configuration, dimensions, and basic components, shoring towers from different manufacturers may vary in some other features such as basic-frame design, assembly method, and carrying capacity. the present paper works with all kinds of commonly used towers with no limitations.

For more detailed information on types of shoring towers used in this study like dimensions, properties, and load carrying capacity, the reader can check the manufacturers catalogues [e.g., PERI, 1996, DOKA, 2007 and ACROWMISR, 2008]. 


\section{GENETIC ALGORITHMS}

The Genetic Algorithms (GAs) was first introduced by John Holland in the 1960s; then the technique was developed in the University of Michigan during 1960s and 1970s by Holland and his students. In the beginning, Holland's studies were not oriented to design an evolutionary algorithm for solving specific problems, but he was just studying the natural adaptation phenomenon and he was trying to find a method to simulate its mechanism.

Holland published in 1975 the first book that presents the genetic algorithms; it was titled "Adaptation in Natural and Artificial Systems". This book gave a full presentation of the theoretical framework of natural adaptation under the GA, and the method of simulation of the biological evolution (Holland J. , 1975).

Many scientists worked in the field of GA development and its application such as, David Goldberg 1989 ... etc. They developed most of the currently known types of GA, but they all still give Holland the nickname "The father of GAs".

\section{OBJECTIVE FUNCTION}

The objective function for this problem can be written as follows:

$$
\begin{aligned}
& W \min =\left[\left(1_{2 \mathrm{~A}}+1_{2 \mathrm{~B}}\right) \times\left(1_{3 \mathrm{~A}}+1_{3 \mathrm{~B}}\right) \times \mathrm{W}_{\mathrm{p}}\right]+\left[\left(1_{2 \mathrm{~A}}+1_{2 \mathrm{~B}}\right) \times \mathrm{N}_{\mathrm{j}} \times W_{j}\right] \\
& +\left[\left(1_{3 \mathrm{~A}}+1_{3 \mathrm{~B}}\right) \times N_{s} \times W_{s}\right]+\left[W_{U T}+W_{L T}+\sum_{n=1}^{i} W_{M T}\right]
\end{aligned}
$$

Where:

$\mathrm{W}_{\min }$ :Minimum overall weight of one unit of formwork $(\mathrm{kg})$.

$1_{2 \mathrm{~A}}$ : Maximum joist span on towers rows (m).

$l_{2 B} \quad$ : Maximum joist span between towers rows $(\mathrm{m})$.

$1_{3 \mathrm{~A}}$ : Maximum stringer span on towers rows (m).

$1_{3 \mathrm{~B}}$ : Maximum stringer span between towers rows (m).

$\mathrm{W}_{\mathrm{p}}$ : Weight of plywood $(\mathrm{kg} / \mathrm{m} 2)$.

$\mathrm{N}_{\mathrm{j}} \quad$ : Number of joist elements per one unit.

$\mathrm{W}_{\mathrm{j}} \quad$ : Weight of joist $(\mathrm{kg} / \mathrm{m})$.

Ns : Number of stringer elements per one unit.

Ws : Weight of stringer $(\mathrm{kg} / \mathrm{m})$.

$\mathrm{W}_{\mathrm{UT}}$ : Weight of upper tier of shoring tower $(\mathrm{kg})$.

$\mathrm{W}_{\mathrm{LT}}$ : Weight of lower tier of shoring tower $(\mathrm{kg})$.

$\mathrm{n} \quad$ : Number of middle tiers.

$\mathrm{W}_{\mathrm{MT}}$ : Approximate weight of middle tier of shoring tower $(\mathrm{kg})$.

\subsection{Constraints}

Three types of constraints are imposed on the generated solutions to ensure the development of practical formwork elements:

1- Design constraints.

2- Bearing constraints.

3- Stability constrains. 


\section{Design Constraints}

1.The vertical load calculated due to slab condition must be bigger than the minimum value for vertical loads according to ACI 347R-94 for normal conditions equal 4.8 $\mathrm{kPa}$, when motorized carts are used equal $6.0 \mathrm{kPa}$ if this condition not achieved takes the minimum value for vertical loads as the design vertical load.

V.L $>$ V.L min

2.The span of the joists lying between the tower rows (also the spacing of the tower rows) (12Bmax) must be bigger than L2, where L2 = length of the joist, if this condition not achieved then recalculate using bigger section of joist.

$\mathrm{l}_{2 \mathrm{Bmax}}>\mathrm{L}_{2}$

3.The span of the joists lying between the tower rows (also the spacing of the tower rows) (12Bmax) must be bigger than L4Y, where L4Y = the length of the tower in parallel to the direction of the joist, if this condition not achieved then substitute n1 $=\mathrm{n} 1+1$ and repeat until $12 \mathrm{Bmax}$ is obtained that meets the condition.

$\mathrm{l}_{2 \mathrm{Bmax}}>\mathrm{L}_{4 \mathrm{Y}}$

4.The span of the stringers lying between the towers (also the tower spacing within the rows). (13Bmax) must be bigger than L3, where L23 = length of the stringer, if this condition not achieved then recalculate using bigger section of stringer.

$\mathrm{l}_{3 \mathrm{Bmax}}>\mathrm{L}_{3}$

5.The safe carrying load capacity of each tower leg (PT) must be bigger the calculated load carrying capacity per one leg, if this condition not achieved then these solution unsafe try another one.

$\mathrm{P}_{\mathrm{T}}>\mathrm{V} . \mathrm{L} \times\left[\left(\mathrm{l}_{2 \mathrm{~B}}+\mathrm{L}_{4 \mathrm{y}}\right) / 2\right] \times\left[\left(\mathrm{l}_{3 \mathrm{~B}}+\mathrm{L}_{4 \mathrm{X}}\right) / 2\right]$

\subsection{Bearing Constraints}

1. The calculated bearing stresses between joists and stringers must be smaller than allowable bearing stress according to type of material for these members see

2. The calculated bearing stresses between stringers and the u-head of the shoring towers must be smaller than allowable bearing stress according to type of material for these members.

\subsection{Stability Constraints}

1. The cross section of the stringers (main beams) must be bigger than the cross section of the joists (secondary beams).

2. The remain height from the ceiling height after subtracting the height of sheathing, joist and stringer elements and also after calculating the number of tiers must not exceed $60 \mathrm{~cm}$ (where the $60 \mathrm{~cm}$ are the recommended extension for both upper and lower jack spacers

\section{OSAF MODEL}

A computer model called OSAF is built using MatLAB to solve formwork problems. The model is build by G.U.I toolbox to make it easer for the user. The objective function of this model is to minimize the weight of the overall formwork system. Six steps are required to run OSAF model as follows: 
Step 1 .Run OSAF.

Step 2. This edit box (Fig(3)) contains two parts, the first includes project informations such as name ,type location and user name, while the second part includes project data such as slab thickness, slab height, concrete unit weight, loading conditions (normal of motorize), type of secondary and main beams material. The user press SAVE, then SHEATHING buttron to go to step 3

Step 3. This edit box (Fig(4)) includes information about plywood sheathing such as thickness, dimensions, weight, stiffness capacity EI, section capacity in bending and rolling shear. The user can add, save and delete to the data base and returns to edit box shown in Figure (3)

Step 4. The user press BEAM button to go to edit box shown in Figure(5).In this part of model the user defines the dimensions and section properties for secondary and main beams. Then ADD,SAVE, or DELETE to go to edit box shown in Figure (3).

Step 5. The user press S.TOWERS button to go to edit box shown in Figure (6). The edit box contains all information about the shoring towers. The user can use the types stored in model data base or ADD,DELETE other shoring towers types, press SAVE will return to edit box shown in Figure (3).

Step 6 OSAF can perform two kinds of calculations for formwork, the first is done when press Manual calculation as shown in Fig(3), the output of this step is as shown in Fig(7), in this case model can check the structure safety of all members of formwork but it may not be the optimum (i.e the minimum weight), the second is done when pressing GA calculation in this case the model will search for the optimum solution using formwork components stored in the data base stored before by the user.



Figure (3): Main program screen. 


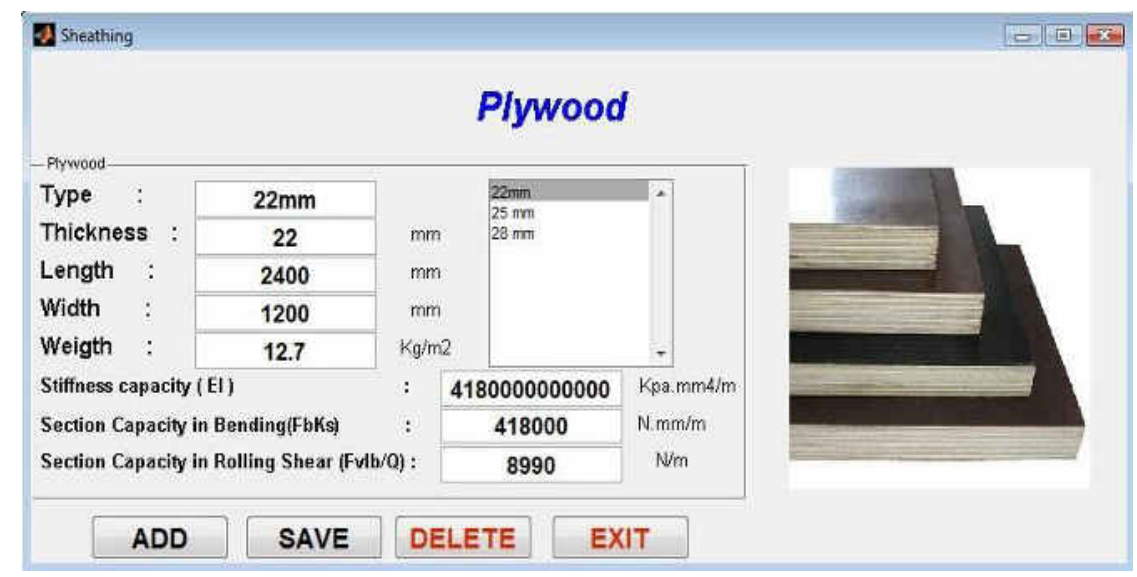

Figure (4): The sheathing screen.

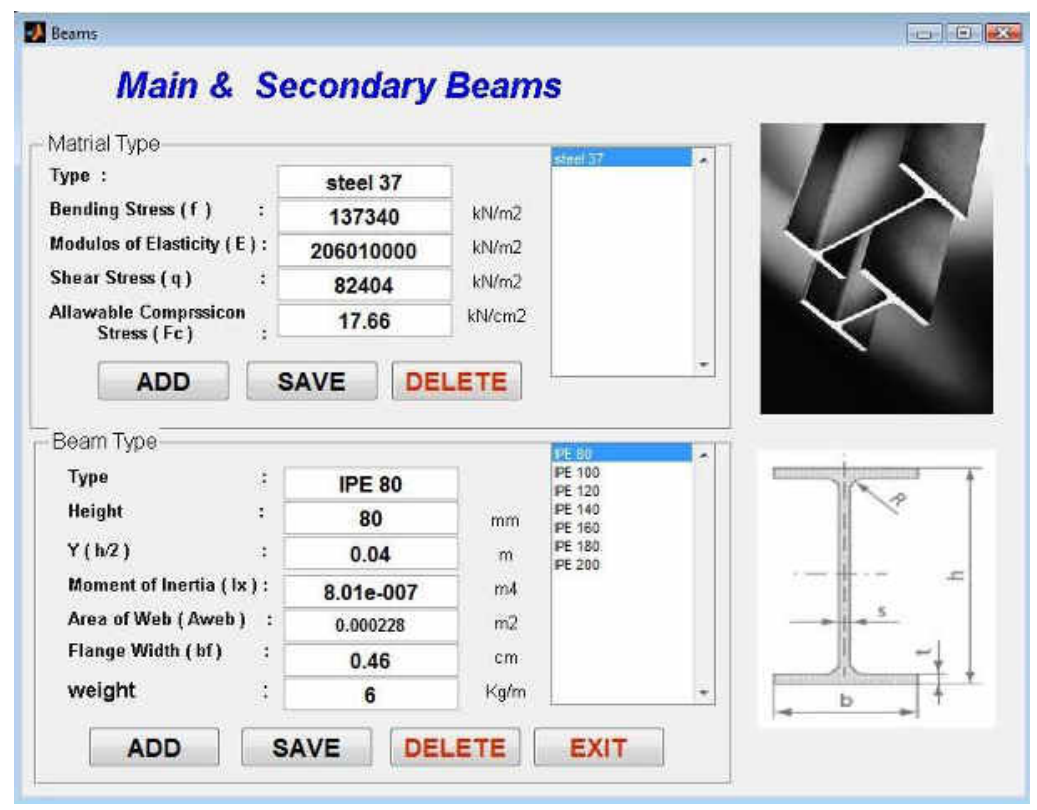

Figure (5): The beams screen (main and secondary beams).

\section{NUMERICAL EXAMPLE}

The numerical example is to select the optimum minimum weight for slab of deck bridge of thickness $300 \mathrm{~mm}$. The formwork components consists of plywood sheathing, steel hot rolled steel sections for secondary and main beams and shoring towers as vertical members. OSAF can find the optimum minimum weight using the data base stored before by the user.

The out put of the model are as shown in Figures $(8,9)$. Figure (8) contains project information's and project data such as slab thickness, slab height, concrete unit weight, loading conditions ,type of material for secondary and main beams while Figure (9) contains all formwork items such as plywood thickness, type of secondary 
and main beams and type of shoring tower. Also, the output contains secondary and main beams spacing, number of tiers. The total weight of modular unit of formwork is shown. Figure (10) shows the relationship between fitness value and generation . Fitness value which represent the minimum formwork weight

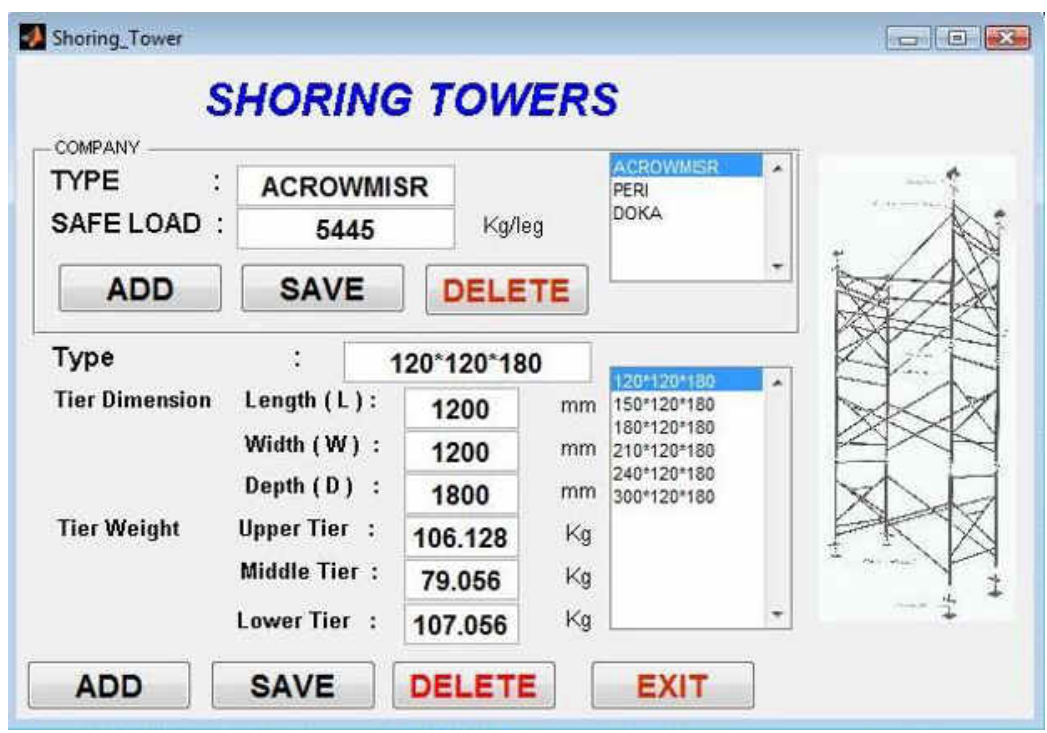

Figure (6): The shoring towers screen.

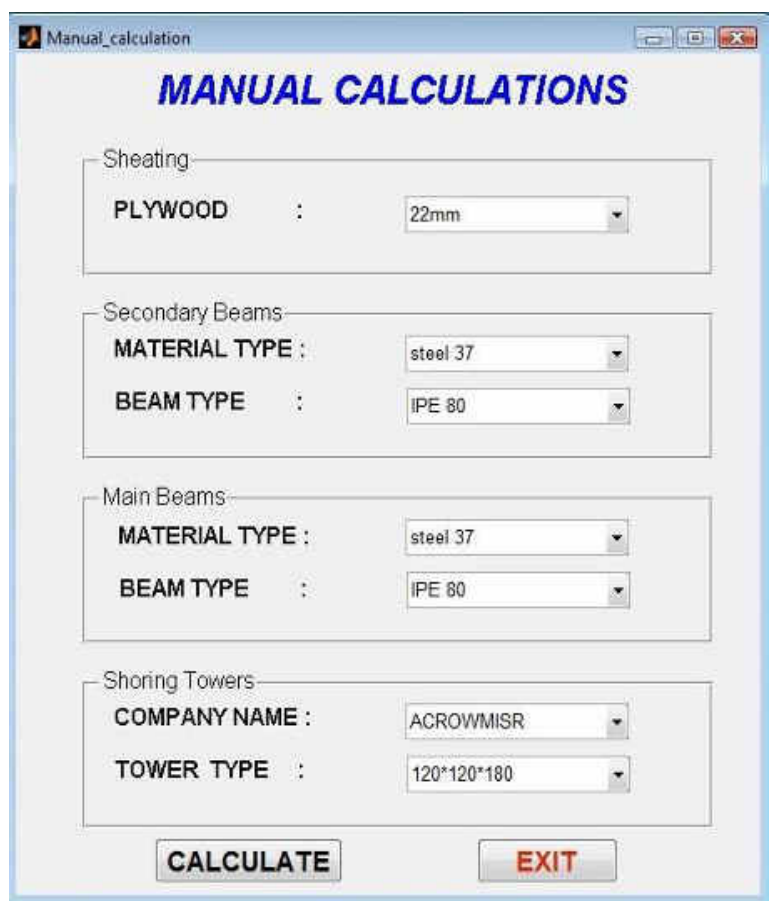

Figure (7): The manual calculations screen. 


\section{NUMERICAL EXAMPLE}

The numerical example is to select the optimum minimum weight for slab of deck bridge of thickness $300 \mathrm{~mm}$. The formwork components consists of plywood sheathing, steel hot rolled steel sections for secondary and main beams and shoring towers as vertical members. OSAF can find the optimum minimum weight using the data base stored before by the user.

The out put of the model are as shown in Figures $(8,9)$. Figure $(8)$ contains project information's and project data such as slab thickness, slab height, concrete unit weight, loading conditions ,type of material for secondary and main beams while Figure (9) contains all formwork items such as plywood thickness, type of secondary and main beams and type of shoring tower. Also, the output contains secondary and main beams spacing, number of tiers. The total weight of modular unit of formwork is shown. Figure (10) shows the relationship between fitness value and generation. Fitness value which represent the minimum formwork weight

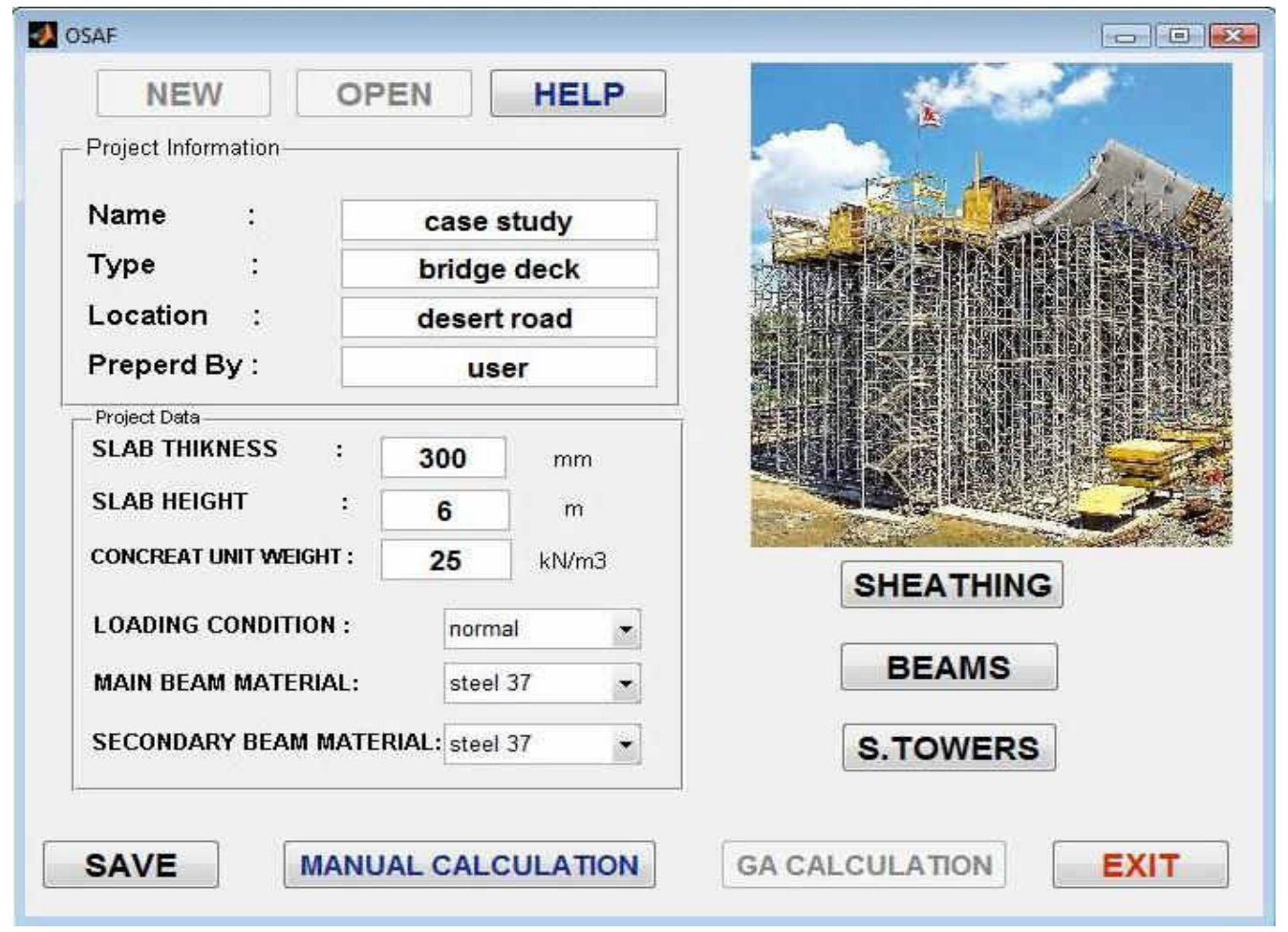

Figure (8): The case study project information's. 


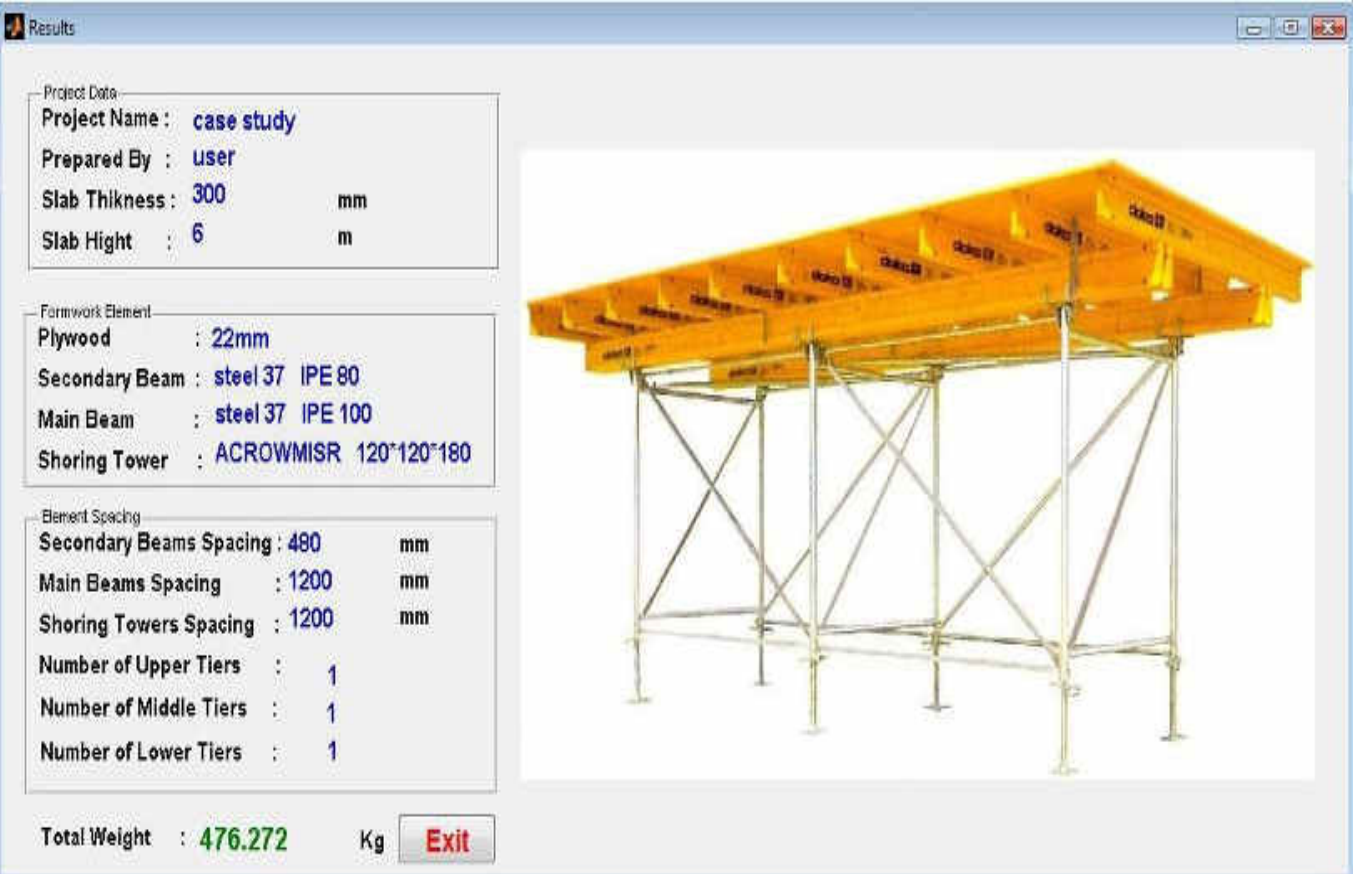

Figure (9): The case study project result (on the result screen).

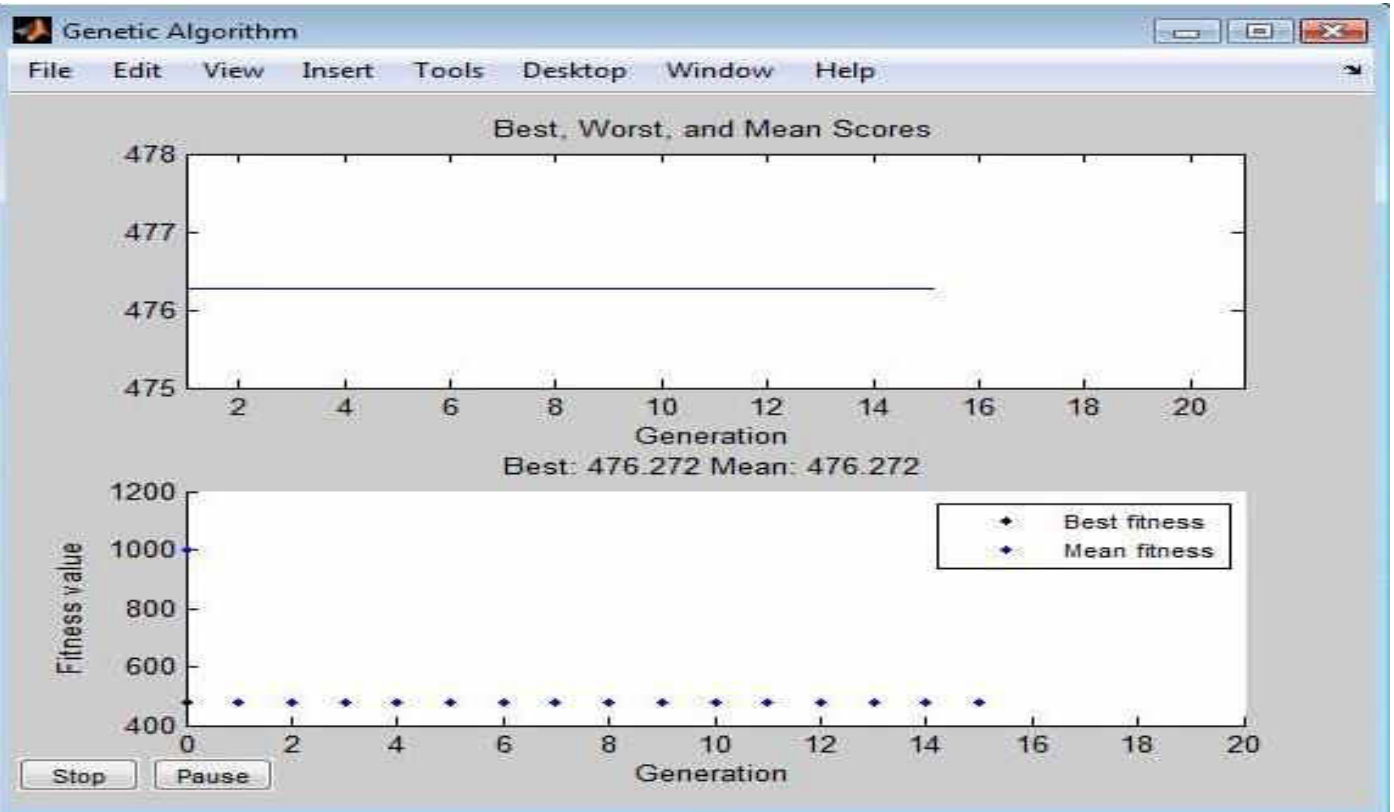

Figure (10): The case study project result (on the graph screen). 


\section{CONCLUSION}

A computer model (OSAF) has been presented for determining the minimum weight for heavy and height reinforced concrete slab formwork system. The formwork consists of plywood sheathing, secondary, main beams and multi tiers shoring towers. OSAF designed to find the optimum weight using genetic algorithm as an optimizer. OSAF is easy to use because it depends on numbers of input and out put screen made through MATLAB. OSAF is tested and use to solve a numerical example as shown before.

\section{REFERENCES}

1. Hurd, M. K. (1995). Formwork for concrete (6th ed.). Michgan: American Concrete Institute

2. Peurifoy, R. L., \& Oberlender, G. D. (1996). Formwork for concrete structures (3rd ed.). New York: McGraw-Hill

3. Bennett, C. P., \& D'Alessio, M. S. (1996). Handbook of temporary structures in construction. New York: McGraw-Hill.

4. Shapira, A. (1995). Formwork design for high elevated slab construction. Journal of Construction Engineering and Management, 13 (3), 243-252.

5. Shapira, A. (2004). Work inputs and related economic aspects of multitier shoring towers. Journal of Construction Engineering and Management, 130 (1), 134-142.

6. Shapira, A., \& Goldfinger, D. (2000). Work-input model for assembly and disassembly of high shoring towers. Journal of Construction Engineering and Management, 18 (4), 467-477.

7. Shapira, A., Shahar, Y., \& Raz, Y. (2001). Design and construction of high multitier shoring towers: case study. Journal of Construction Engineering and Management, 127 (2), 108-115.

8. Hanna, A. S. (1999). Concrete formwork systems. New York: Marcel Dekker.

9. Peurifoy, R. L. (1976). Formwork for concrete structures (2nd ed.). New York: McGraw-Hill.

10. Hurd, M. K. (1989). Formwork for concrete. Detroit: American Concrete Institute.

11. Ringwald, R. (1985). Formwork design. Journal of Construction Engineering and Management, ASCE , 391-403

12. Christian, J. (1987). Use of integrated microcomputer package for formwork design. Journal of Construction Engineering and Management, 603-610.

13. Tah, J. H., \& Price, A. D. (1991). Interactive-computer-aided formwork design. Computers and structures, 41 (6), 1157-1167.

14. DOKA. (2007). Products, Know-How, Service. DOKA Gmbh.

15. PERI. (1996). Component Catalogue. PERI Gmbh.

16. Holland, J. (1975). Adaptation in natural and artificial systems. Ann Arbor, Mi.: University Of Michigan Press.

17. Holland, J. (1992). Genetic Algoritms. Journal of Scientific America, 44-50. 


\section{تصميم وتثييد الأبراج الساندة متعددة الطوابق}

بعتبر تصميم الثدات مرحلة هامة ومؤثرة فى تكلفة العناصر الانثائية|لخرسانية المسلحة عند تتفيذ اى مشروع

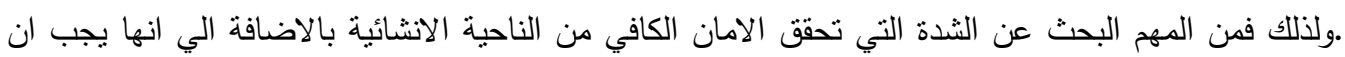

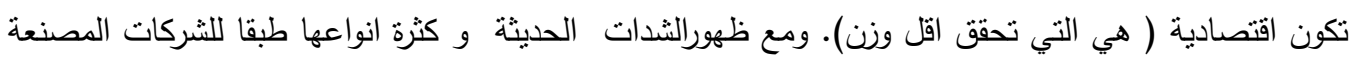



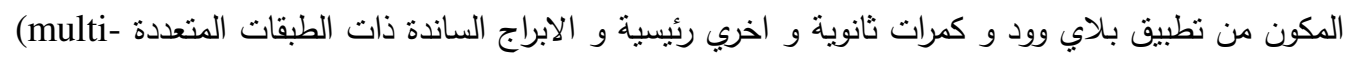
Stiers shoring towers) البلاطات الثقيلة والمرتفعة مثل بلاطات الكبارى .



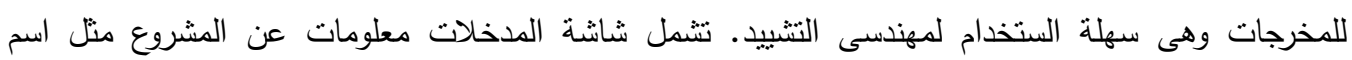
المشروع ومكانة ونوعة واسم المستخدم و معلومات عن البلاطات الخرسانية نفسها مثل سمك البلاطة وارتفاعها

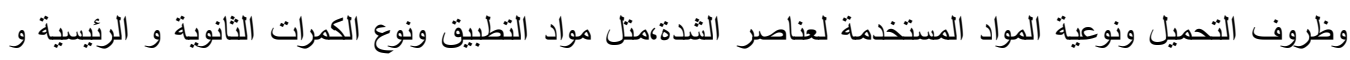

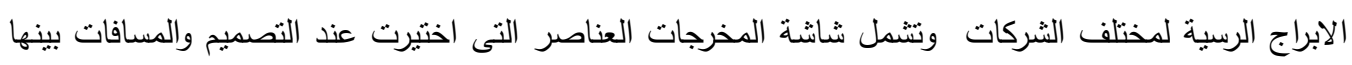

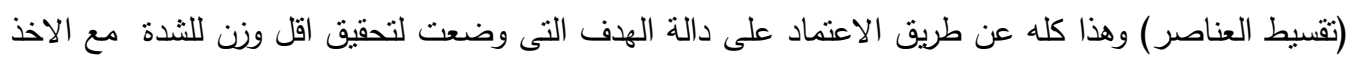
فى الاعتبار شروط الامان ويتم الحل بحيث تستوفى كل القيود المطلوبة مثل قيود التصميم والتحميل

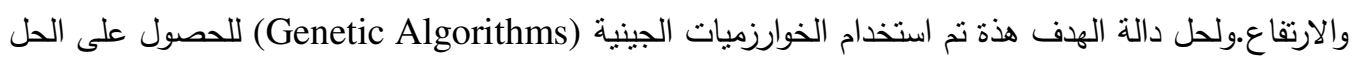
الامثل لما تتميز به من قوة فى حل هذا النوع من الدوال 